\title{
The Use of Retelling Stories Technique in Developing English Speaking Ability of Grade 9 Students
}

\author{
Sasitorn Praneetponkrang (Corresponding author) \\ Master of Art Degree student in teaching English as a foreign language Program, \\ Graduate School Nakhon Ratchasima Rajabhat University \\ 340 Suranarai Rd., Muang District, Nakhon Ratchasima 30000, Thailand \\ E-mail: rimigho_31@hotmail.com \\ Malinee Phaiboonnugulkij \\ English Program, Faculty of Humanities and Social Sciences \\ Nakhon Ratchasima Rajabhat University \\ 340 Suranarai Rd., Muang District, Nakhon Ratchasima 30000, Thailand \\ E-mail: malineerabbit@hotmail.com
}

Doi:10.7575/aiac.alls.v.5n.5p.141

Received: 10/07/2014

URL: http://dx.doi.org/10.7575/aiac.alls.v.5n.5p.141

Accepted: 03/08/2014

\begin{abstract}
This article aims to advocate retelling stories technique for developing speaking ability of grade 9 students in Thailand. Morrow's theory (1981) and other scholars in retelling stories technique are presented. This technique is integrated in the lesson plans following Morrow's framework. Narrative text of short stories which refer to daily life and social including pictures have been used for each lesson plan. Students are trained to work as a group using story's mind map, illustrations, and role-playing activities in class. There are three main steps of teaching retelling stories: before retelling (alternative techniques), while retelling (students' practice by using activities of brainstorming, role play, and discussion) and retelling story. The lesson plans will be piloted with $159^{\text {th }}$ graders. This preliminary study is expected to provide an example of useful techniques in improving speaking ability, thus, it is expected to be used in other foundation English courses for Thai students.
\end{abstract}

Keywords: Retelling stories, Speaking ability, Teaching speaking

\section{Introduction}

Due to English is an international language that is used by the majority countries in communications, business, education, diplomacy, technology, and international organizations. Many countries agree to use English as a global language (Graddol. 2006: 87). There are more people using English than other languages to be the center of communication around the world. The globalization of English influences over Thai education; consequently, Thai speaker cannot deny all significant trends around the country. Moreover, English speaking is an important in communication because many foreign countries speak English. In 2015, Thailand will be participated in the ASEAN Community to do a commercial market with other neighbor countries Thai students thus should improve speaking skill to communicate effectively with foreigners (Nantanach Sriprachayakul. 2013). Also, story retelling is an assessment tool that evaluates students' learning in an English speaking or writing's comprehension of the story (Morrow, et al. 1986) and story retelling can direct the learner to achieve in the development of an English speaking skill. Story retelling is a part of learning to speak activities for this study, and story retelling takes places when students retell the important details of stories or stressing the focus on comprehension. Furthermore, story retelling provides students to analyze a story and creates a language in speaking or oral, and students get to know the related terminology (Schienkman. 2004). Using the pictures to retell a story can be very useful in language learning. It provides a vision to support scaffold comprehension of learning language. Story retelling helps students begin understanding events, plot, and characters as they build vocabulary and comprehension skills. But most importantly, students have the basic skills to start doing story retelling on paper by doing mind mapping. The story's apprehension and story retelling are effective in improving the active participation and interaction by peers work learning in the restoration story through role playing (Pellegrini and Galda. 1982). Teaching for developing knowledge in story retelling needs the interaction of students' learning that can assist teachers for checking their students' thinking (Teale \& Sulzby. in press). The main goal of story retelling is retelling the story's meaning from the interactive and cooperative in class learning. The interaction of retelling a story also depends on the psychological ability on story retelling which is independently or autonomously (Teale. 1984). 


\section{Teaching speaking skill and definition}

The capacity to speak a language is the basis of human communications. Speaking a foreign language is the most requirements of the four skills and speaking a second language is a central skill (Bailey and Savage. 1994, p. vii). The speech becomes the communication which advent when people communication has already been proved by the theory of communicative competence and teaching the speaking skill by using activity that is the major point of English as a second language classroom (Hymes. 1972). In learning speaking ability in the classroom, Ferris and Tagg (1996a, 1996b) offered that the extensive authentic practice is an important to improve speaking skill in ESL class. Students need to be the participant of doing activities such as discussions, peers working, answering, and asking questions in class. Moreover, another theory also supported that discussion and doing speaking report is the activities that should be done in class, for example, a study of the oral presentation of the business class. Students must learn how to plan and conduct a business meeting giving a speech and participate with colleagues (English and Grosse. 1995). There are some theories defined speaking definitions. First, Rebecca (2006: 144) mentioned that speaking is a part of daily life that people acquire since they are children. Second, Gert and Hans (2008: 207) stated that speaking is a speech processing that involves the speaker and receiver to recognize what speech's contents. Third, Brown and Yule (1999:14) identified speaking is the complicated information because it is difficult to find what people say. In this present study, speaking is performances in the classroom is focused and types this productive performances are displayed as below.

\subsection{Types of classroom speaking performance}

According to the previous study from Brown (2007:327-330), types of classroom speaking performances are in six categories. Imitation is the first category that is a very limited portion of the classroom speaking time that may legitimately take time to build. "Human tape recorder" speech, for instance, learners practice using the imitation sound or attempt to identify some of the vowel sounds. This type of imitation is performed not for the purpose of having a meaningful interaction, but it is focusing on the elements, especially some of the pattern language. The intensive is the second type of the classroom speaking performance that is going one step beyond the imitative. It includes any speaking performance that is designed to perform some of the sounds and grammar of the language. Intensive speaking also can be self-initiated or it can be a part of any pair work activities that students are going over some form of language. Responsive is the third category of speaking performance. It is a good positive deal of students' speech in the classroom. Even though, students doing in a short reply, their replies are sufficient in learning, and their speeches can reach the meaningful and authentic learning. Transactional (dialogue) is the fourth category of the classroom speaking performance. Transactional language points out to the exchanging specific information while students have a conversation in the classroom. They can do more negotiate speech more than only responsive. Interpersonal (dialogue) is the fifth category of this English- speaking performance in the classroom. Interpersonal is focus on the purpose of maintaining social relationships than the transmission. Students can speak in a little trickier by using some of these factors, such as, slang, a casual register, colloquial language, emotional language, ellipsis, sarcasm, and a cover "agenda." Finally, students who are the intermediate to advanced level are in the group of using extensions (monologue). They can practice the speaking reports, summary, or doing short speech. For these six categories of the classroom speaking performances, the writer also agrees that teachers have expected that students can perform speaking and succeed in the oral production. In addition, to support increasing of students' speaking skill, the principles of teaching in speaking skill is the important topic that would be interpreted in the next part.

\subsection{Principles of teaching speaking skill}

The principles for teaching speaking skills are the key to encouraging students to able to speak English. It makes the students have interest and not bored in class. It will help students have fun, enjoy talking in class, and they can express their thoughts freely. There are several principles for teaching speaking skill (Bailey. 2005: 7).

1. Recognizing the difference between learning a second language and language learning of the international context.

Students need to learn the speaking skills for the two contexts, including foreign language and second language situations. The target of a foreign Language context is not for social communications. Meanwhile, the second language is the target of language communications in society.

2. Focusing on both fluency and accuracy.

Fluency in a language is very important that teachers aware to help students use language quickly and confidently, but sometimes students might feel hesitations of using the language. The accuracy of language is also necessary for students to use the language accurately and students can communicate with others.

3. Support students to have opportunities of using group work or pair work.

During the lessons, the target of language is students can increase speaking skill because they join in group work and pair work activities. Furthermore, when teachers change the conversation, students also can get through diverse speaking.

\section{Task speaking planning by negotiation for meaning}

Bailey (2005: 7) also suggested that the communication progress is the target of the language that students have the interaction in this process. The understanding language is necessary from the task of negotiating for meaning.

5. Guidance and practice have designed to classroom activities that involved in 
both transactional and interaction are speaking.

The communication between people is the social purposes that call the interaction speech. While, transactional speech is the communication of getting something done and it involves the exchange of goods or any services. Therefore, teachers can take these above principles for teaching in speaking skills and assist students in achieving of language learning. Also, teachers need to prepare the suitable speaking activities and types of speaking test are explained in the next topic.

\subsection{Classroom speaking activities}

Classrooms speaking activities are necessary for teachers to use the various activities to practice students speaking skill. Harmer (2001: 271-276) stated that teachers can use these activities in the classroom:

\section{Acting form a script}

Students take part in this activity by making their own script show in front of the class and teachers need to allow students to prepare to write on the dialogue before doing the performance in the classroom.

\section{Communication games}

Students join the communication game with their friends. For example, they work in pair to play the game and help each other to solve the puzzle. They might draw a picture and describe what they try to explain; students can find the differences and similarities between the pictures.

\section{Discussion}

Discussion in class speaking is encouraging students to become confidently. Students will get the benefit to share their opinions solving the problems each lesson and it supports students to drop the difficult things during learning.

\section{Prepared talks}

Students have the opportunities to choose their own choice for presentation in front of the class. This activity helps students are ready in speaking, but the topic that has prepared would not be formal natural conversation. Therefore, students can practice from their writing because every conversation would be on the note, not from the script.

\section{Questionnaires}

Teachers are the major resource to help students design the questionnaire process based on the topic they need to learn. This questionnaire activity can direct students to the basic of written work, discussion, and preparation talks.

\section{Role play}

Role play is another enjoyable activity that students can do during learning in class. For example, students would be asked to design of the situation and retelling a role of the sample of a traffic accident. One student plays as a policeman, another is acting as a bus driver, and the rest play as a victim. Students think and create a situation and retelling it in class without using scripts.

In sum, teachers apply speaking activities in classrooms to help students to understand more so the role of teacher is also very important in teaching in classrooms. This topic is explained as follows.

\section{The Role of the teacher}

Teachers can help as a prompter while students are studying in class; teachers have a high influence to insist students of speaking which would be explained in three aspects. First, teachers have a role of the prompter in helping students. When students cannot think what to say, students forget some point so teachers can help as a prompter. Second, teachers are the participants. If students try to produce their speaking, teachers are good animators to help them. The last aspect is teachers should give feedback to students. In speaking class activity, students will meet their approach more if teachers also help to give feedback to improve their speaking skill.

In short, when teachers finish doing the role in teaching, they need to evaluate the students' progress in learning by making the speaking test in the next paragraph.

\subsection{Types of speaking test}

The speaking test is an important tool to evaluate students speaking ability. Thronbury (2007:125-126) also explained that there are many types of speaking test such as interview, live monologue, recorded monologues, role-play, and collaborative task. First, interview is an easy testing type that teachers can set up in the classroom. English skill of writing or reading task could be set in classes while students are called out for their interview. Although, the interview does not come out from their problems, it should be as natural interview whether the interviewer is a learner's teacher or the external examiner. It means that the situation is a difficulty conducive to the more informal speech patterns conversation. It is not surprisingly that students tend to underperform in the conditions of the interview. Moreover, it is difficult to eliminate the impact of the interviewer about the style of questions in the interview. Even though, a teacher setting the interview for classroom testing is easy type; it is difficult for teachers to make students speak fluently during the interview especially if the interviewer is an assessor at the same time. However, there are solutions to avoid some of these problems to suggest. The interviewers start talking general things that are not formal speaking before interview because it can help reducing students' nervous of questions interviews. The interviewers should use pictures or select a topic about the interview that will focus on helping students to talk in smoothly without confident. Moreover, the interviewees should have a short time for two minutes to prepare themselves before the start of the interview. Second, 
Live monologue is a speaking test that teachers use in the classroom. The live monologue test is about people who have been described as the candidates to provide a short talk presentation on the pre- selected a topic. This test will help to reduce the impact on the interviewer and the candidates must show the evidence of their ability, which is not always in an interview. Questions and answers may be included if other students take the role of the audience and to provide evidence of their ability to interact naturally. But speaking and presentation is correct when it shows that students like and prefer. Third, the test monologue, recorded is less stressful more than public performance. For the unofficial test, they are more practical ways that the live monologue is not. Students can record themselves talking about their favorite sport or hobby, for instance, in a room nearby to the classroom with minimal disruption to the class. Usefulness of the test recorded could be done after the event and the other examiners can rate the recording and their rating could be compared to make sure standards. Fourth, the role-playing is another type of testing and teachers can use in the classroom. Students also participated in a role play in class and style of playing is same as using for testing. In addition, this role could be played either by testing or another student. However, it is difficult to control the influence of conversationalists. The role should not include complex or very fancy. Students can use the information that they provided. For example, students use information from brochures to book excursions with the agency. Therefore, this test is effective if it is necessary for them to learn. Fifth, collaborative task and discussion is the last type of speaking test. This test is similar to role-play, but the learners need to be themselves while doing the test without doing role-play. For example, the learners can respond from their own opinion with the statements are related to the point of the topic. Evaluating and scoring tasks are presented in the following parts.

\section{Teaching Techniques}

3.1 Narrative

The researcher used discourse types of narrative in this study and it is a form of short stories in the text study, and related to story retelling for improving speaking skill in this study. Many theorists also gave the definition of the narrative as discourse type. Brewer (1980), Chatman $(1975,1978)$, and others explained narrative as a discourse type. These are many discourses types' names of the narrative, such as mystery, western, science, fiction, fairy tale, short story, biography, drama, literary novel, newspaper, history, instructions, recipes, biography, message, fable, parable, advertisement, descriptive, and expository. The categorizations of these discourses describe its type. For example, each discourse type will have a part of content, structure, style, effects, and transmission. Furthermore, the obvious explanations of the narrative are a discourse type and they are presented as below.

Brewer $(1980: 223)$ specified that the narrative is a discourse that attempts to gather the series of events that takes place in a language and the reason or coherence. He gave the example of a text description of the boy saw a dandelion; he took dandelion to his mother. The explanation is a discourse tries to fill in the body language form and needs the understanding. A discourse has represented in the language model underlying the abstract logic of the induction, classification and comparison. Chatman (1975: 295) also defined that the contents of narratives are the events' chain that contains the characters and setting, the object and person's performance. Moreover, the features of narrative discourse have the definition of below:

The plot is one of the goals of the actions and emotional state. (cf. Chatman. 1975: 1978, Lehnert. 1981: 1982 and Propp. 1968).

Theme is a concept or idea of the story (Bisanz et al., 1978)

Point is a feature of the content that is generated interest of the story. (Wi-lensky, 1982: 373).

Social interaction is a mutual or interrelated relationship among people. Foreshadowing is representing in advance.

Flashback is the interjection of the incident earlier.

Repetition is the recurrence situations.

Character is the actor for the existence of the story (Chatman. 1975: 1978)

Setting is about time, place, and/or props (Mandler and Johnson. 1977)

Problem or Conflict is hinder of goal (Steinberg and Bruce. 1980)

Goal and Intention are the meaning of the desire and want of the story.

Plan is the means to achieve objectivity.

Action and Event are about happening in the story.

The ending is the consequence of an action (Mandler and Johnson. 1977)

In addition, other definitions of the narrative have focused on the separating meaning of both product and process. Frye described that the narrative is the text which has the elements of constructs or categories; also Polkinghorne and Bruner defined narrative that is the tool for human making, and the process which specified investigation and later clarify about people's experiences. However, narrative certainly identifies in a diversity ways and it is considered as a conflict sometimes. There are some theorists who gave the different definition of the narrative. Barthes (1977:251) stated narrative as having endlessly distinguishes the form of the famous stories, and narrative could be presented in the legend, fable, myth, tale, novella, epic, history, cinema, comics, News, conversation; he also presented narrative can occur to every age, place, and society. Linguist William Labov (1972: 359) defined narrative is one way of telling the 
past experiences of doing the matching a verbal sequence of clauses to the occurring result of the events that really happened. Ricoeur emphasized the result of the narrative is the stories of human lives or human experiences, and he has finished his conclusion in 1984. Abbott (2002:12) explained narrative is the representation or retelling of a series of events and he mentioned the action in events. Therefore, we simplified and joined the narrative's definition by focusing on sequence and action. Retelling is retelling a story from events or situation in a specific period sequence. The contents of the story need character, focalization, and a plot which can tell how the narrative organizes and present to the audiences. Bal (1985:4) explained that these contents of stories are important tools that they show a description, in a way of enhancing the story. Apart from the narrative definition, the story and characters also would be indicated in the next.

\subsubsection{Story and Characters}

Maybe the narrative's element is a story which it's told through characters. Abbott (2002: 13) has supported the ideas that the story is the situation or event's sequence. Even though it is retold from the first or third person, past or present perfect tense, chronologic or non-chronologic, and the intention of the audience; it is the same story because basic story is same. He also predicted that it has rarely caught directly in the story unless people understand the story through these constructions such as characters, actions, point of view, and the text's organization. Therefore, we can understand a story by relating on character, focalization, and plot because the elements of narratives and story are interlinked. The important elements of the story include events, action and actors, and character (Bal. 1985). Characters are necessary for story retelling because they are narrative constructs of the events. The Little Red Riding Hood's tale is the example of a story that the wolf is an important character. He said that an important character helps the audience understand the story. However, Little Red also may consider as the central character because the story is focusing on her. Therefore, both of a wolf and Little Red are important character in this story. Moreover, the learners need to understand the story and characters; they should comprehend about point of view and plot of the story which are illustrated below.

\subsubsection{Point of view or focalization}

The story's events consist the point of view that is the cause to develop and help learners to understand the story. Bal (1985: 100) defined that the point of view is the concept of the story and it points to the characters and actors. The narrative is an instrument for teaching story retelling which includes a point of view that the learners will get the main points of story retelling. Moreover, the point of view's effects on the instruments education that is not only emphasizing on the text, but also uses to specify the point of the story. Thus, it is a part that could be changed without changing the basic elements of the story.

\subsubsection{Plot}

The plot has described in various meanings from these theorists. First, Cobley (2001: 239) explained the plot is like a chain that linked a story and it is images which related to each other. Plot also has a duty to make in prioritization of events and characters that are important in developing the story. Second, Abbott (2002:16) regretted that the plot is missing in use and it causes to disqualifying. He noted that English speakers also combine the plot of the same thing of the story. Third, Czarniawska (2004) defined that the narrative plot can answer to the questions of "Why?" Therefore, the conclusion of using the narrative text is useful in this study, the teacher should realize of these narrative parts that have been described in the previous. It will become the basis of helping students to learn to speak by story retelling. In order to cover this study, story retelling is very important and it is explained in the next paragraph.

\subsection{Story retelling}

\subsubsection{Definition of retelling}

This study focuses on retelling from speaking with students in secondary school through grade 9 students. Retelling is reading or listening that learners remember from reading or listening and retell what they recognize either through orally or in writing (Morrow. 1989:40). It is a tool for developing student's apprehension (Morrow. 1996:267; Morrow. 2005:396). Johnson (1983: 54) stated that retelling is the most directly accessing in teaching and the reaction result of the reader from the text. Retelling signifies the reader or the listener understanding of learning's and creates new construction of character and reflects in retelling apprehension. Retelling helps readers or listeners to respond to the structure of stories regarding the personal explication of each message. It is the process of involving children in creating text and also allows interoperability between adults and young learners. Retelling motivates learners about the text for both integration and personalization that also helps learners view what the content components of the message and how the text related to their experiences. Also, Koskinen et al. (1988:892) explicated that retelling is a useful teaching technique to encourage students in communication, and improves an oral language comprehension. It provides the readers to separate between the point of ideas and supporting details and retelling helps students to understand the text's meaning. It advocates students to learn about the story's elements such as plot, setting, and characters. Readers or listeners retell the story from their remembering through speaking, drawing, or writing; and retelling can help students rethink to the ways of enhancing in retelling the story comprehension (Owocki. 1999). Moreover, Brown and Cambourne (1987) defined that students need to think more before they retell the story from their understanding. Students also integrate of retelling concepts such as vocabulary and story's structure. Gambrell, Koskinen, and Kapinus ( 1991) interpreted that retelling is focused in the understanding of the important role that oral language displays in the creation and sharing of meaning.

Vygotsky's (1978) definition of higher mental functioning that affect to incorporation sociable association continues to cause debate. Application of Vygotsky's theory in literacy occurs on the development of social relationship between 
children or learners and the environment is associated learning part of reading, writing and oral language. (See Ogle, this volume). Teaching for developing knowledge in retellings need the interaction of students' learning that can assist teachers for checking their students' thinking (Teale and Sulzby, in press).

Holdaway's (1979) model of instructional development teaching by states that children will get the most directly benefit with their first experience with learning from the storybooks which are prepared by adults to solve the situation problem in learning and teaching. Teachers will ask children to answer and tell their ideas (In this case, story retelling), and teachers will assist children by providing information when needed. (In this case, guide the retelling). For instance, in the events of both learners and teachers agrees to create integrated, interactive creation and the relationship with the printed text while learning. One of the main goals of retelling is telling of the stories meaning by learning interactive and cooperative in class. Interaction of retelling stories also depends on psychology which affect to adult and children, is a meaningful share of mind; and children can recall the story from the ability of stories as independently or autonomous (Teale. 1984; Vygotsky. 1978).

\subsubsection{Using story retelling to develop comprehension}

Retelling is the part of speaking activities in class learning and retelling stories is an assessment tool that helps students in developing of learning English comprehension. Clay (1979) and Smith (1978) have given suggestions of reading to help students in learning the language. The young learners interchange with adults for the reading books can reach the learner to develop language comprehension, spoken language, and construct of story's framework (Blank, et al.1971; 1975). Brown's (1975) research shows that the active participation of the young learners in stories, rehabilitation promotes an understanding of the subject. Restoration has defined in the study of Brown's ideas, thinking about the incident is a matter of stories and arrange the story events in chronological sequence. The sample of his ideas is the mental restoration of events in students to create an internal representation of the story. Pellegrini and Galda (1982) found the story apprehension and retelling efficiency can improve from the active participation and interaction with their peers in the restoration story through role-playing. Similarly, Amato and Taylor (1973) found that retelling capacity allows children to have a large and active role in the restoration and collaboration between the teller and the listener.

\subsubsection{The use of story retelling in the classroom}

Even though, students who do not have any experience on story retelling might face the problem of the difficulty in retelling process. In contrast, morrow (1985) found that children have difficulty in retelling, but doing practicing in retelling a story could be helped. However, increasing the quality and training facilities for retelling can help students succeed on the story retelling process. Teachers should teach the lessons before you read or listen to the teaching content because the children would be asked to retell the story.

Moreover, the teaching is instruction also depending on the retelling target. If teachers focus on instructing intention or chronological test such as teaching children to pay attention to what happens first, second and next. Teaching or assessment students' capacity is the purpose that needs to use in class for integrating information and give a reference for the text. Teaching students and referring to each feeling or experiences that related to the text. The teaching technique of asking students to story retelling meaning by doing the pre and post discussion from stories will help to develop story retelling (Mitchell and Morrow. 1984; 1985). Morrow suggested that to practice in retelling and discussions about the quality of retelling. Tape and role play can use to encourage students to specify their strengths and weaknesses.

Guideline for retelling. The guideline that offers about the approach to knowledge and ways of children's retelling (Morrow. 1985). He highlighted on the gathering of some structural features has described by both Fitzgerald and Gordon; setting (introduction about characters, time, and place), Theme (the beginning situation that affect the main character to act or face a trouble), Plot (events that the main character affords to reach the goal or solving the trouble), and Resolution (problem's solution). Moreover, teachers can use the interventions as the prompt's form of questions and, use these prompts when students have difficult time in moving through retelling on their own. (Glazer and Brown. 1993: 116).

Ask students to retell the story and students can say. "Not long ago I read (putting name of the story). Teachers can encourage students by asking them to retell stories to friends because their friends have never known it before. "Young students provided with the equipment from the story to help them in story retelling (Morrow 1985). Sometimes children should retell the story to others who actually do not know about.

1. Teachers can use the following motivated words if necessary.

A. If students face the problem in the beginning, teachers should suggest them to start with these words "Once upon a time "or" one there was...."

B. If students cannot continue stories and stop retelling before the end of stories, teachers can help by urging them by asking these questions, "Can you tell what come next from a story?" and "What will happen?". However, teachers voice should make students do not feel exciting.

C. If students stop retelling and cannot continue even though teachers help to ask the encouraging questions in B, teacher should help to ask the relevant questions to the point of view in stories. For example, "What was the reason that Jane moved to London?"

2. When students cannot retell the story or if they do not know enough of the sequence and detailed in the retelling, teachers should help to motivate gradually them from these questions. For example; 
A."Once upon a time or "Once there was...

B. "Who was in the story?"

C. "When did the story happen?" (Such as, day, night, afternoon, summer, winter?)

D."Where did the story take place or happen?"

E."What was the main character in the story?"

F."How did he or she try to solve the problem in this story? What did he or she do first from this story)?"

G. "How was the problem in a story solved?"

H. Teachers ask students to tell about "How did the story end?"

Children's capacity for story retelling will decide how much the instruction and scaffolding are needed. Scaffolding relates to adults' supporting all responses for children that they cannot answer it. Scaffolding helps children to find what they expect in doing the complete scaffolding offers the helping as much as students need, even if the teachers finish retelling of the whole story in the early guideline lesson. When children begin to find out how to deal with story retelling by themselves, then scaffolding should be reduced.

Stories retelling's sample from teachers' instruction. A six year old girl is the sample of story retelling in this section. She got the knowledge of story retelling from a teacher and she also earned the benefit in learning.

\subsubsection{The teacher role in teaching story retelling}

According to Isbell (2002: 28), a teacher can use retelling to encourage students in learning by using their imagination, explaining their ideas, and students using the ideas to transfer to the plot, settings, and characters of the story. Teachers and parents are important to encourage young learners in retelling by reading to them or a teacher is a strategy to promote the related stories comprehension and explicate vocabulary (Gambrell \& Dromsky, 2000; Geva \& Olson, 1983; Soundy, 1993). A teacher and parent's scaffolding to children from the storybook reading and this includes asking open-ended questions, asking students to make predictions, and engaging a child in elaboration and explication. (Cliatt \& Shaw. 1988). Teachers and parents play an important role in influencing the behavior of children. Children who have grown up in a good environment of rich knowledge in reading, which is keen to read and they are more likely to read since they're young until reader become successful(Clark and Durkin. 1966; 1984). One reason is clearly, the rational behavior of the adults around the children such as parents and teachers could be a sample in story retelling for children.

Story retelling is to provide a model for children and need to do it better in the processing of expressing. Teachers can use voice to show the dialogue by different activities. Story retelling is similar to the magnificent presentation so teachers can help children by retelling it slowly by animation. Then, teachers can observe how the teaching is conducted by videotape or record and make the critical teaching technique. As mentioned earlier that retelling is not commonly used in school because it is difficult and takes time for the children, but there are several ways to succeed in the retelling. The technical guidance in the classroom for the practice and improve the language skills will be able to retell the story of the children. Children can also retell the story through the tape recorder and listen by themselves, or teachers and other people listen to children retell. Stories could be retold by using a book to help. Even though young children (pre-school and kindergarten children), it has recommended starting trying to get a picture of a book to help children in story retelling. Morrow (1989) explained that prompting students in thinking can direct them to understand in retelling.

In addition, Daniel (2007) has stated that teachers' role in the teaching process of story retelling and it is a pattern of good practice in primary teaching. A researcher agrees that teachers have important roles in teaching story retelling steps in class as the following:

Pre retelling: Teachers should familiarize students with retelling introduction; how to focus on the main idea, how to support students, and how they work and how to connect to the logic.

While retelling: Teachers provide students with the questions for guideline.

After retelling: Teachers provide feedback related to the production of the student.

Moreover, teaching retelling steps is developed by the authors, and Benson \&Cummins (2002) stated that teachers can teach retelling for four steps such as pre retelling, guideline while teaching retelling, story map, and retelling. Students will learn pre retelling as the first step and teachers will teach students to think about retelling. Next, teachers teach students to prepare retelling and students get knowledge of story structure. Then, students arrange to retell the story by doing story map and students retell the story in the last step. Therefore, the writer decides to use the teaching steps of pre retelling, while retelling or guideline to arrange retelling, retelling by speaking and teachers give feedback after retelling which are refer to Daniel, Benson, and Cummins for the lesson plan in this study. The writer considers that many teachers have struggled in teaching students to retell, so that using the teaching these main steps in retelling can be benefit to handle in the lesson plan. Thus, the writer summarizes the learning process which is based on Daniel, Benson, and Cummins by drawing a flowchart of figure 1 to explain lesson plan and using retelling techniques in the classroom. 


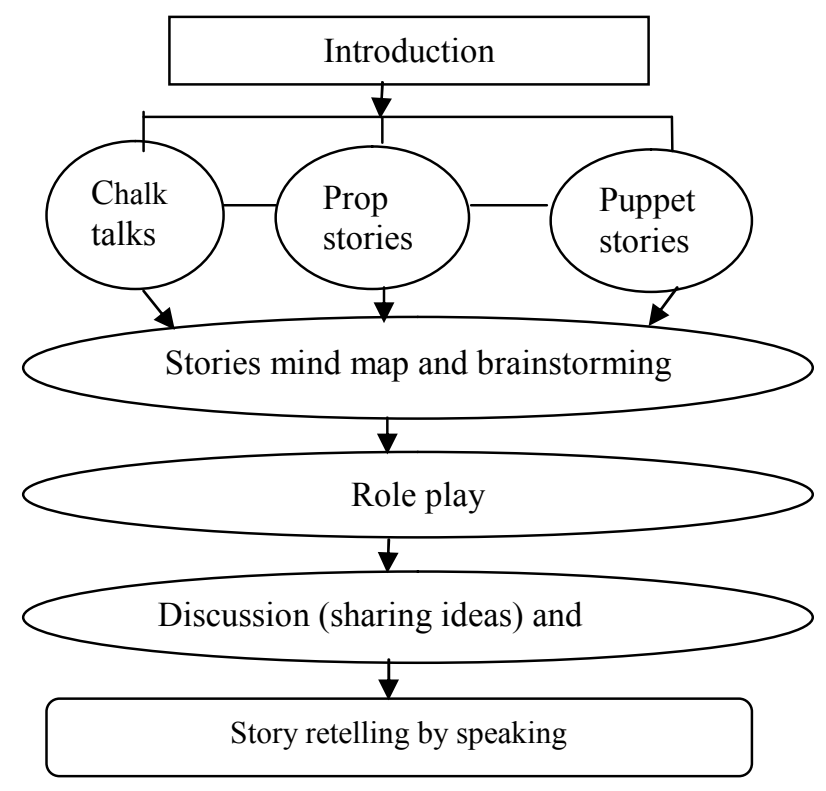

Figure 1. story retelling techniques and learning process.

Source: Daniel (2007), Benson, and Cummins (2002); Lesson plan

Morrow (1981:1982:1984:1985:1986), Mitchell (1984), Pellegrini (1982), Galda (1982), Isbel (2002); retelling techniques.

The researcher uses the story retelling techniques for teaching story retelling of Daniel (2007), Benson (2002), and Cummins (2002) in learning steps of lesson plans, and Morrow (1981:1982:1984:1985:1986), Mitchell (1984), Pellegrini (1982), Galda (1982), Isbel (2002) for retelling techniques which are shown in figure 2. First, the teacher begins the class with an introduction to the lesson objective. A teacher continues to explain narratives or short stories by using chalk talks, prop stories, and puppet stories, which are the alternative techniques that use in each lesson. Second, students learn story structures which are consisted plot, point of view, setting, characteristic, and ending, and students begin doing the story's mind mapping, role play, and discussion. Third, students perform in the story retelling accordingly and a teacher gives feedback after students finish producing story retelling.

\section{Pre retelling:}

1. Introduction: a teacher needs to explain the objective and the contents that students must study each lesson and students try to think about retelling. Teachers should familiarize students with retelling introduction; how to focus on the main idea, how to support students, and how they work and how to connect to the logic.

2. Chalk talks: a teacher teaches by drawing during guideline the story retelling on the board (Morrow. 1981).

3. Prop stories: a teacher uses story retelling as a prop such as toys, animals, and staff of the story in order to help the narrator retells characters of the story. (Morrow. 1981).

4. Puppet Stories: Teachers help students by preparing many kinds of puppet such as hand puppets, stick puppets, finger puppets so this way help students who are shy to feel more relax during doing story retelling (Morrow. 1981).

Guideline retelling or while retelling:

1. Students will learn story structures which are consisted plot, point of view, setting, characteristic, and ending. Teachers also provide students with the questions for guideline.

2. Story's mind map: it motivates students to story retelling from their imagination and retells their ideas from the free thinking (Isbel. 2002).

3. Role plays: it is the act out of characteristics from stories or real-life situation that students need to do it in the learning process (Morrow 1985, Pellegrini, and Galda. 1982)

4. Discussion (sharing ideas): it supports the ability of retelling by doing the previous and post discussion from stories (Mitchell and Morrow. 1984:1985).

\section{After retelling or Post retelling:}

1. Retelling in independently: students retell stories independently in class.

2. Teachers give feedback to students after they finish produce retelling.

There are many techniques which include a lot of fun in class, though it is used by teachers, students, and audiences in a personal or in a group. Teachers have known to promote story retelling techniques to encourage students to retell the story (Morrow. 1981).

Flannel boards. A teacher uses flannel board in teaching story retelling and uses it to show the characters of the stories and place the material in the library classroom. Then encourage the children to use a flannel board to retell the story during stories of reading recreation and tell a limited number of characters that occur in the story such as requested Mr. Bear (Flack. 1932) or hats sold (Slobodkina. 1947). 
Chalk talks. Chalk talks are about the story that has drawn while retelling it (Morrow. 1989). Chalk talks are an effective technique when do in a large Chalk board so that the story would be retold without interruption from beginning to end. In addition, the same technique that could be used for murals hangings on the wall or paper charts and paper with colored pencils and the narrator uses the narrator to feel the release to the end of the chalk, which selected as the image of the simple, but you do not need as a good artist. The sample story has written as chalk talks such as a story of Harold and the Purple Crayon (Johnson. 1955). Children will be quite keen to try to use chalk talks when they have seen this technique of retelling conformity it.

Prop stories. Story retelling as a prop such as toys, animals, houses, and stuff of the story to help the narrator retells characters of the story. However, the prop needs as suitable while it is used as a guide to retell. Galdone (1972) offered the story sample which is Goldilocks and the Three Bears. He suggested the prop of this story which is following these samples; three stuffed bears and yellow- haired doll, three bowls, and three chairs. Owocki (1999) described that using a prop as prompt can help students to retell a story and teachers guide students by drawing characters from a story. In addition, Soundy (1993) suggested that using a prop toy as an effective tool will encourage students in story retelling events.

Puppet stories. Teachers help students by preparing many kinds of puppet such as hand puppets, stick puppets, finger puppets so this way help students who are shy to feel more relax while doing story retelling; then students trust that the puppets can retell the story. There are the best suitable samples for retelling by puppet from dialogue's stories which have the limitation of characters such as Little Pigs (Galdone. 1970) or the three Billy Goats Giuff (Brown. 1957). Owocki (1991) also stated that finger puppets can provide students in understanding of the story's frame or structure. In addition, Bennett (2002:24) explicated the benefit of using puppet in classroom can help to provide students' opportunities for expression a story when they are in a group of communication working. Also, Ruddell \& Ruddell (1994:112) explained the benefit of puppet story is used in creating the individual views. The use of puppets story in teaching might encourage students to show out their ideas in retelling (L.Piazza. 1999).

Sound stories. In this technique, sound effects to the story retelling and the sounds could be made by voices or rhythm instruments. Teachers can teach students from the sound stories and it is good to motivate students to retell stories independently. The theorist has suggested that the book that is good at retelling with sound such sound is Noisy Book (Brown. 1939), Too Much Noise (MCGoverm. 1967) and Mr. Brown Can Moo. Can You? (Seuss. 1970)

\subsubsection{Lesson Plan}

According to Brown, Ed (2007: 164-167) mentioned about the format of a lesson plan in these six steps.

First, a teacher needs to design a number of goals in each lesson plan. A goal might be generalized, but it provides a pedagogical for a teacher's context.

Second, objectives will be stated explicitly in the lesson plan. A teacher explains what students gain knowledge from the lesson. These are explicit statements of the lesson plan objectives that might insist a teacher. 1) Teachers need to be ensuring what they want to achieve in the instruction. 2) Teachers preserve the uniformity of their lesson. 3) Teachers predestine whether or not they are trying to achieve too much. 4) Teachers assess students' learning success at the end. Objectives in lesson plan must be clearly featured in term of what students will learn and perform. However, teachers should avoid vague statements like these. 1) Students will study about the passive voice. 2) Students will practice some exercising listening.

3) Students will make the selection of reading. 4) Students will discuss in class for homework assignment. Objectives should be identifying an overall purpose that teachers will attempt to succeed in teaching and learning at the end of class time. However, there are two kinds of objective that the author supports such as term objectives, and enabling objectives. Terminal objectives are the learning outcomes that teachers will be responsible for the assessing. Enabling objectives are the steps within a lesson that build upon each other and eventually direct to a terminal objective. These are the examples:

Terminal lesson adjective:

- Students will successfully request information about ordering food and paying a bill

Enabling objective:

- Students will understand and produce the following 5 new vocabulary.

- Students will comprehend the airline schedule reading.

- Students will produce questions by using when, where, and what time.

- Students will produce the appropriate polite of requesting form.

Third, material and equipment are needed to arrange in a lesson plan. Teachers should list materials needed and arrange them to the classroom such as a tape recorder, a poster, and some handouts.

Fourth, procedures are necessary to provide in the lesson. Teachers should operate the clearly lesson with the guidelines for planning and ensure that the plan is includes an opening statement or a warm-up activity, activities and techniques are set in which teachers have considered appropriate proportions of time of the whole-class students work, pair work, small group, teacher talk, and students talk; and closure. 
Fifth, the assessment is a critical step in the lesson plan. Teachers need to understand that not every lesson ends with a quiz or testing; or evaluation of the composition of classes' separation. However, the evaluation can take place in regular classroom activities. Some assessments may have to wait a day or two until students have the ability or the opportunity to create learning. Teachers will need to ensure that the evaluation will assess the performance of students in learning opportunities and teachers should consider for evaluation to (a) assess student achievement and maybe (b) make appropriate adjustments to plan lessons for the next day.

\subsubsection{The advantages of story retelling and theories}

According to the writer has studied the theory of retelling a story, the writer finds the useful of story retelling from these theories that will be explained in the next. Blank and Sheldon (1971) reported that the semantics and the complexity of the sentences in the language of children aged 4-6 years have increased when children have asked to repeat the sentence. Due to teachers read about the courageous story to children, and they can retell it. Similes and Kuhns (1976) also found that children of six to eight years old can retell a story. Post test has used to rate and interpret of experiments that students can also retell the story after listening.

In the middle of 1980, Morrow had studied on series to evaluate the efficacy of a retelling strategy with young children. She focused on comprehension; concept, story structure, and oral language which were developed as variables. Morrow (1985b:648) surveyed to teachers and they gave the opinions that retelling was difficult to use in children, so Morrow was motivated from teachers' opinions to find out the way to help in teaching retelling. Kindergartens were participants of his studies in 1985b; 1986. Teachers or parents read stories to children and those experimental groups make the oral retelling. Students or children demonstrated oral retelling with the significant gaining of language's knowledge in each day.

Morrow (1984, 1985, and 1986) continued to study three different studies with kindergarten students, to decide specify guiding advantages of teaching and learning that are specific of story retelling. Children of the experimental group retell stories after listening in the last eight weeks of their instructions. When the children are offering to help improve retelling, the most important is found in the complexity of the experiment group in oral language and understanding of the story. The feeling of the story retelling and the structure of the elements and structure of the dictators of the story, originally built by the young children who are considered is a success at a lower level that are significant in the area through the test.

Despite the obvious benefits of the survey from kindergarten, children show that they are lack of chance in story retelling in school. Teachers' opinions of story retelling are difficult to learn for young learners (Morrow. 1982) can cause students do not have an opportunity in the retelling. However, there is enough information insists that story retelling is the valuable education which should be promoted in the classroom.

Students have involved in story retelling that reflects on the holistic vision of language comprehension. The listener or viewer needs to integrate into the story as well as related parts of the story to one another and to customize information to either of the background of them. Experience of the incident is different from the traditional method of teachers. Teachers use little question that has been placed on the need for students to respond to the specific information about the messages. (Morrow, et al. 1986).

Two years later, Morrow (1988) reviewed the accumulating literature and described the multiple uses of retelling in reading comprehension assessment. She mentioned that retelling was challenge task and children needed time to practice. Students should be told from teachers and they could retell stories and teachers should provide props in some cases to help students. Morrow also suggested using narrative and informational material in teaching retelling as an instructional strategies.

Morrow had been researching in 1996 and writing about retelling over ten years and she summarized her observed. Morrow (1996: 267-268) explained that retelling can indicate students' abortion and restoration of text information and the learners' comprehension. Readers or listeners are allowed to instructor responses from their personal or individual from the text.

In 2005, Morrow emphasized the benefits of retelling. Children can develop the comprehension of narrative text's structure through retelling and including experience, original thinking, and organization though with literature experience. Morrow also mentioned about the need of setting a purpose of retelling and providing opportunities to practice.

Brown and Cambourne (1978) developed retelling procedure by testing it in New Zealand and the department of education in New Zealand approved a comprehension strategy of retelling in 1980s. For a number of weeks or days, topic and genre were immersed in students' learning. Then, children shared their prediction of a story before reading the text, and they retold or rewrote it without referring to the original work. Cambourne stated that retelling demands students to focus on the text's meaning, remodel, and reflect on it.

Papas and Golden (1990:21) committed a meta-cognitive in the studies base on retelling more than a decade. They used cognitive processes in research's examine which is included reading comprehension. Many researchers are interested in this retelling procedure. Papas and Golden also made the critical examine of 81 oral retelling research and they studied had been conducted with preschool and elementary grade students.

Rose, Cundick, and Higbee (1983) launched that retelling or sparring verbally much increase language comprehension in early elementary learning disabled children. The finding of these theories is important, especially since it happens the 
shortage of reading. Disabled children have been occurring as participatory in learning with a manufacturing defect strategy (Antonio, Hallahan and Kauffman, 1976; Wong and Wong Foth, 1977).

Another study from Gambrel, Pfeiffer, and Wilson (1985) showed that students in the fourth grade participating in story retelling and they can enhance language in the high performance result when using silent way when doing the test passages.

These studies show that verbal imparting of what learners read or listen to learn significant in reaching understanding and discourse recognition. The reader or listener gets knowledge in learning the organization and storage of character data. GamBrell,Pfeiffer, and Wilson (1985) defined that enhancing in story retelling by referring the content processing will support students to plan and promote learning in participated actively in management and engaging language efficiently.

\subsubsection{Alternative strategies in story retelling}

These are the effective techniques that help students for story retelling. The independent retelling occurs, and it does not take whole class time by using these techniques. Students are cooperative entertaining and learning, so they can encourage retelling with their friends in the classroom.

\subsubsection{Brainstorming}

Brainstorming is a simple and effective skill that used for creating of thinking and ideas. Students can use brainstorming in class activities, but it takes a short time of doing brainstorming. Brainstorming is the primary process that is followed by other activities. For example, groups may use the ideas generated from brainstorming, which is the basis of discussion's type. After students finish doing the brainstorming sessions, their ideas should be categorized and evaluated as much as possible. Moreover, it should be used by students in follow-up activities and groups may arrange the elements in priority for getting into the story. For example, members may evaluate the suggestion of topics and characters. Therefore, the rules of brainstorming will be suggested to students and teachers. First, All ideas that students acknowledge should be recorded excepted only the obvious jokes. Second, it should not have any criticism to be made for the suggestion. Third, groups' members should create brainstorming on one another's ideas because, in the final of analysis, no ideas belong to any individual. Fourth, Leaders should claim ideas or comments from members who are quite silent and then give them positive reinforcement. Fifth, in brainstorming, the quantity of showing ideas is important than the quality, but it doesn't not reduce group's members of thinking creatively and intelligently (Orlich, Harder, Callahan, Trevisan and Brown, eds. 2010:261).

\subsubsection{Role play}

Role playing is a technical process that focuses on group learning. Students act out in life or simulated situations. Students need to have training for using the technique effectively. Preparation can help students enjoy doing the roleplaying and they will get some enjoyable experience. However, students should not over concern about the interaction that might occur in other situations and they should understand from the personal attacks. It is important that the participants of doing this technique should understand the difference between regular acting and psychodrama. Role players and all participants who are in the discussion should refrain from psychoanalysis or pretending that they are psychologists. Role play is not being emphasized on the psyche of the participants, but it emphasizes on the acting or drama of the situation and demonstrating of the different characters in the story or situation (Orlich, Harder, Callahan, Trevisan and Brown, eds. 2010: 263-264).

In addition, role-playing can use with all grade students of academic and it could be used to investigate the topic or any situation (McCormick, 1998:264). Role playing also be the effectively in developing students' social skill (van Ments, 1999:264). Teachers also use role- playing in the classroom especially in the literature classes to assess students' apprehension level (Belizaire, 2006:264). Therefore, role- playing can allow some of the drama in the classroom but it also depends on activity and plan.

\subsubsection{The benefits of using pictures illustrate stories to teach story retelling.}

The researcher has studied several theories and found that using pictures are advantages in teaching and learning. According to Schienkman (2004), the author stated that story retelling provides students to analyze the story and creates a language in speaking or oral, they get to know the related terminology. He also stated that using the pictures to story retelling can be very useful in language learning. It provides a vision to support scaffolding comprehension to understand learning language. Meanwhile, Latuheru (1988) mentioned that pictures consist many functions of teaching and learning. First, pictures help the learner to translate ideas into more realistic form. Second, pictures are easily used in the schoolbooks, newspapers and magazines. Third, pictures can be used in the different kind of academic levels. Fourth, pictures help teachers to save time and energy. In addition, Raimes (1983) stated that using pictures help to provide in the sequence events such as the picture events of a comic strip. Moreover, a set of parallel pictures can help to provide learning material that offers the learner on vocabulary, sentence structure, and organization.

Furthermore, Klasek (1972) stated that using pictures have several advantages. First, pictures are the medium of communication, and it is inexpensive and pictures help to manage in events, and can adapt using pictures of many subjects. This picture has a multiplicity of uses-by individual students on the bulletin boards and the flames on the board. In addition, pictures can assist in preventing and correcting misconceptions. It can also translate images of the event, described the process of extending experiences, draw a comparison, to show the continuous focus of attention, and development decision. 
Additionally, Wright (1989) stated those pictures are very useful to use in helping students for story retelling, experience, or understanding things that they present, etc. He also agreed that pictures help students to enhance more in the general context. Dale (1969) supported that pictures have its own advantage that bring students to close to the point of visual context. They can also be compressed or deal with the reality of teaching and changing the size of objects too small or too large to comprehend the sight of the actual dimensions.

In addition, Sulaeman (1988) argued that using pictures are an important visual media because they can show captions concrete ideas. They can make the reader understand the ideas or information and they are clearly seen even more clearly than the written or oral.

Brown, et al. (1983) stated that the picture may improve the literacy of students, for example, a picture that might help them to understand the concepts. There are some valuable uses for pictures, for instance, to stimulate interest of students and help the reader understand and remember the contents.

\section{Related Research}

The researcher found a number of related researches about retelling stories for both positive and negative results. First, the research of Rizqon (2011) studied the use of animated film for improving Indonesia student's speaking Skill in story retelling of grade eight students. The research results had shown that the use of animated as the media made the effective teaching in story retelling for improving speaking skill. Second, the research of Farida (2011) had studied about the developing students' story retelling ability through collaborative learning techniques. She used the research sampling from VIII A students of SMPN 2 Semarang for grade eight by focusing on the speaking ability. The first goal of her research was tried to explore to what extent CL or collaborative learning techniques could increase the ability of the VIII A students of SMPN 2 Semarang in story retelling. Meanwhile, the second goal of this study was to investigate the CL or collaborative learning could develop a manner of the VIII A students of SMPN 2 Semarang in story retelling. The result of this research had shown both negative and positive. The positive result was the successful development of students' English speaking ability after using CL technique in story retelling, but the negative result had shown that the $\mathrm{CL}$ technique could not be successfully developing on student's manner in retelling stories. Third, Fajri has studied the research in 2012 about the ability of the eleventh grade students in story retelling at SMK Rohmatul Ummah Jekulo Kudus by using cartoon film. She studied that story retelling of the eleventh grade students after teaching by using the cartoon film and to find the difference between being able to retell the story of a grade eleven years before and after instruction using cartoons film. Results of the study showed that the ability to retell the story of the eleventh grade students could improve speaking skill after using cartoons film to teach students. He also recommended the use of cartoon film in teaching because students can more easily learn to speak English. Fourth, the research of Aliakbari \& Mohsennejad (2014) had studied the effect of the story retelling opinion gap task on Iranian EFL student's speaking skill. The samples of this research were 29 students from Zaban Sara Institute in Khorram Abada and they were studied in an intermediate of English. The purpose was to investigate the efficiency of story retelling opinion gap on the promotion of Iranian EFL students. The participants were divided into the control groups and experimental. Also, a quasi-experimental was the research design, and the tasks had three strategies such as pre, while, post. The researchers analyzed the result from t-test statistics, and found that students speaking skill can be promoted by story retelling opinion gap.

Fifth, Pinandhita had studied her research in 2011 of class 2I students at IKIP PGRI Madium University about the improving students' speaking skill by retelling technique using video. She explained the purposes of the study in two purposes. First, she investigated students' speaking proficiency after using story retelling technique by using video. Second, she wanted to find students' motivation in the speaking class. However, the sampling of this research was 34 students of the class 2I of IKIP PGRI Madiun University. Then, this research had shown the positive results that are the benefit of education. Retelling technique by using video can improve students' speaking ability. She also found that story retelling technique by using video can improve student's motivation in a speaking class. Sixth, Trina D.Spencer (2009) had studied her research on the effect of intervention narrative retelling the story of preschoolers' story retelling and building the personal story generation skills at Utah State University. She examined the effects of intervention on a story retelling and personal story skill to preschoolers. The researcher selected seven students who attended preschool at Logan Head Start to be the samples in this study, and the researcher used short stories and story pictures in this study. Moreover, the researcher used materials, activities, and instructor to help in increasing students' story retelling and individual story. Results have shown that the narrative intervention could improve students in narrative retelling and individual story generation skill. Also, the results could direct the participant's to achieve in narrative retelling. The researcher calculated scores from INC or the index of narrative complexity and found that the pre narrative to post narrative intervention for personal generations could interpret to an improvement story retelling. Finally, Sasitorn Suwanpattama had studied her research in improving students' English speaking by retelling story task after watching film activity in SALLC at the Rajamangala University of Technology in 2009. She investigated English speaking skill of students through using retelling story after watching the film in Self-access Language Learning Center or (SALLC) of 50 students in the second-year Hotel. The instruments of her research were pre-test, post-test, and film. The score of pre and post test were calculated by using mean and percentage. There were two results of this research. The first result was students' speaking ability has been a little bit improved. She also found that retelling story after watching the film could not help improve students in grammatical and lexical knowledge. However, the activities that used in this study could improve their pronunciation and intonation, and fluency. 
Therefore, the researcher concludes from these related researches that there are most positive results of story retelling. In contrast, there are some negative results of story retelling that are explained from the above research. The beneficial results of story retelling will be developed in other studies, and teachers can use story retelling as a teaching tool.

\section{References}

Abbott, H. Porter. (2002). The Cambridge Introduction to Narrative. Cambridge: Cambridge UP.

Arunee Wiriyachitra. (2001). A Thai University English Scenario in the Coming Decade. Thai TESOL, 14(1), 4-7.

Attapol Khamkhien. (2010). Thai Learners' English Pronunciation Competence: Lesson Learned from word stress Assignment. Kasetsart University, Thailand. Journal of language teaching and research, vol.1, No.6, 757-764, November 2010.

Bailey,K.M. and Savage,L.eds. (1994). New way in teaching speaking. Alexandria, VA: TESOL.

Balley, M. Kathleen. (2005). Practical English language teaching. New York:MC. Graw-Hill ESL/ELT.

Biyaem, Suda. (1997). Learner Training: Changing Roles for a Changing World, Education Innovational for Sustainable Development. $3^{\text {rd } U N E S C O-A C E I D ~ I n t e r n a t i o n a l ~ C o n f e r e n c e, ~ B a n g k o k . ~}$

Boonchom Srisa-art. (2000). Preliminary research. $6^{\text {th }}$ Suriwiyasan, Bangkok.

Brain Paltridge and Sue Starfied. (2013). The Handbook of English for Specific Purposes. $1^{\text {st }}$. Wiley-blackwell.

Brown, Gillian and Yule, George. (1999). Teaching the spoken Language. Cambridge University Press.

Brown, H.,\& Cambourne, B. (1987) Read and retell: A strategy for the whole language/natural learning classroom. Portsmouth, NH: Heinemann.

Daniel, A.K. (2007). From Folktales to Algorithms: Developing the Teacher's Role as Principal Storyteller in the Classroom. In 'Early Child Development and Care',177(6,7). London: Routledge

Dhanasobhon, S. ( 2006). English language teaching dilemma in Thailand. Retrieved January, 2013,[Online].Available:http://www.curriculumandinstruction.org/index.php?lay=show\&ac=article\&Id $=539134523 \&$ Ntype $=7$.

Gambrell,L.B.,Koskinen,P.S.,\& Kapinus,B.A. (1991). Retelling and the reading comprehension of proficient and lessproficient readers. Journal of Educational Research, 84(6), 356-362.

Good, Carter V. (1973). Dictionary of education. New York: McGraw-Hill.

Graddol, D. (2006). English Next. London: British Council. Accessed Feb 27, 2011[Online]. Available : http://www.britishcouncil.org/learning-research-englishnext.htm accessed.

H. Douglas Brown. Englewood Cliffs, NJ: Principles of Language Learning and Teaching, 2nd ed. Prentice-Hall, 1987. Pp. xvi +285 .

H. Douglas Brown. (2007). Teaching by Principles an Interactive Approach to Language Pedagogy, 3 rd ed. Pearson Education, 10 Bank Street, White Plains, NY

Hughes, Rebecca. (2006). Spoken English, TESOL, and applied Linguistics:Challenges for Theory and Practice. Great Britain: CPI Antony Rowe.

Hymes, D. (1973). On Communicative Competence, in Sociolinguistic, J.B. Pride and J. Homes, Eds. Harmondsworth: Penguin.

Isbell, R.T. (2002). Telling and retelling stories: Learning language and literacy. Young Children, 57, 26-30. Retrieved [Online]. Available :http://www.naeyc.org/yc/

Johnson C. (1958). Harold and the purple crayon. New York Harper \& Row.

Johnston, P.H. (1983:54-56) Reading comprehension assessment: A cognitive basis Newark, DE: International Reading Association.

Longman. (2011). Longman Dictionary Online. [Online]. Available : http://www.ldoceonline.com /dictionary/satisfaction [2009, November 20]

Maggi Savin-Baden and Claire Howell Major. (2010). New Approaches to Qualitative Research. Great Britain by TJ International Ltd.

Morrow, L.M. (1984). Effects of story-retelling on young children's comprehension and sense of story structure. In J. Niles\&L. Harris (Eds.), Changing perspectives on research in reading/language processing and instruction (Yearbook of the National Reading Conference Vol. 33) (pp. 95-100). Rochester,NY: National Reading Conference.

Morrow, L.M. (1985). Retelling stories: A strategy for improving children's Comprehension, concept of story structure and oral language complexity. Elementary School Journal, 85, 647-661

Morrow, L.M. (1986). Effects of structural guidance in story retelling on children's Dictation of original stories. Journal of Reading Bahavior, 18, 132-152. Doi: 10.1080/10862968609547561 
Morrow, L.M. (1988). Young children's responses to one to one story readings in school settings. Reading Research Quarterly, 23,89-107.

Morrow,L.M. (1989). Using story retelling to develop comprehension. In K.D. Muth (Ed.), Children's comprehension of text: Research into practice (pp.37-58). Newark, DE:International Reading Association.

Morse, Nancy C. ( 1995). Satisfaction in the white collar job. Michigan:University of Michigan Press.00

Nantanach, S. (2013). Why must Thai people learn English?. Semima: Roles of English. [Online].Available:http://eic152019.blogspot.com/2013/01/why- must-thai-people-learn-english.html.

Office of the Basic Education Commission. (2008). Indicator and key stage indicators of foreign language curriculum. Bangkok: The Agricultural Co-corporative Federation of Thailand.

ONEC. (2003). Education in Thailand 2002/2003. Bangkok: ONEC Publication.

Orlich and others. (2010). Teaching Strategies: A Guide to Effective Instruction. $9^{\text {th }} .25$ Thomson Place Boston, MA, USA.

Owocki,G. (1999). Literacy through play. Portsmouth, NH: Heinemann.

Oxford. (2000). Oxford Advance Learner's dictionary. Oxford : Oxford University.

Paradapat. (2011). The important of English in Thai society. [Online]. Available. http://www.studymode.com /essays/The-Importance-Of-English-In-Thai-544928.html.

Pitsanu Fongsri. (2009). Creating and developing research tools. Dansuttrakarnpim CO., LTD. Bangkok.

Rickheit and others. (2008). Handbook of Communication Competence. Germany

Ruddell,R.B., M.R. Ruddell, and H.Singer,eds. 1994. Theoretical models and processes of reading $4^{\text {th }}$ ed. Newark, DE:International Reading Association.

Sanguansat, T. (1982). How to Encourage English Speaking in Classroom. Curriculum Development Journal. 11 (April-May) 54-57

Soundy,C.S. (1993). Let the story begin. Childhood Education, 69(3),146-149.

Thornbury, S. (2009). How to teach speaking. Malasia: Ocelot.

TNA. (2011, December 3). Research of Srinakarin Wirot University indicates that children learning English is very weak. MCOT [Online]. Available http://www.mcot.net/site/content?id=4ff6725e0b01dabf3c01898a

Underhill. (1987). Test Spoken Language. Cambridge: Cambridge University Press.

Vygotsky, L.S. (1978). Mind in society: The development of psychological process. Cambridge, MA: Harvard University Press.

Wolman, B.B. (1973). Dictionary of behavioral science. New York : Rhinehart. 